\title{
The Project Method as a Means of Implementing a Personality-Oriented Approach in Teaching Mathematics
}

\author{
Fyodor Avdeev ${ }^{1}$, Ivan Avdeev ${ }^{1, a *}$, Tatiana Avdeeva ${ }^{1}$
}

1 Orel State University named after I. S. Turgenev, 302026, 95 Komsomolskaya str., Orel, Russia

\author{
aivan_avd@mail.ru
}

${ }^{*}$ Corresponding author

\section{Keywords: teaching mathematics, personality-oriented approach, project method}

\begin{abstract}
The article is devoted to the possibilities of using the method of projects as one of the effective means of implementing a student-centered approach in teaching mathematics to schoolchildren. The features of the use of project activities in teaching mathematics in the profile school are revealed.
\end{abstract}

\section{Introduction}

In the conditions of contemporary society, mathematics becomes a professionally significant subject. More and more specialties are connected with the direct application of mathematics.

In teaching mathematics, differentiation is of particular importance, due to the specifics of the subject and the psycho-physiological characteristics of students. In such a situation, a personality-oriented approach is an effective technology for teaching mathematics, which involves students' active participation in the educational process based on self-organization. Innovative changes in education are becoming systemic. The search for new forms of work in secondary schools has led to the fact that the practice of project activity has become widely used in practice.

\section{Methodology}

The theory and practice of student-centered learning technology was developed by N. A. Alekseev, V. V. Serikov, I. S. Yakimanskaya, and others, who note that personality-oriented education is put in the forefront [1], [7], [9], [11]. To form a creative personality in teaching mathematics, it is necessary to search for new educational technologies to create conditions conducive to the identification of students' potential.

Project activities successfully fit into the concept of learning, as it is aimed at the practical application of knowledge, independent, creative study of the material. The use of project activities in teaching mathematics increases the motivation to learn, contributes to the deep learning of educational material, and forms communicative qualities.

\section{Study}

The study was carried out in the framework of the project "Innovative Methods of Teaching Mathematics at School", intended for organizing the research activities of Masters enrolled in the direction of "Teacher Education". The purpose of the research is to search for effective methods of teaching mathematics to schoolchildren, including their theoretical substantiation and practical implementation in training. The study was conducted in several stages: 1) the study and analysis of psychological, pedagogical, and methodological literature in the framework of the university's academic disciplines; 2) systematization and generalization of the work experience of mathematics teachers (in the period of teaching practice); 3 ) theoretical substantiation and practical implementation of the identified innovative methods of teaching mathematics (preparation and defense of a final qualifying work).

As one of the effective methods of teaching mathematics was proposed the method ofprojects. It has been established that during lessons of mathematics in the primary school, it is advisable to implement project activities in the form of a didactic game, this contributes to the development of students' motivation to study the subject, reveal their individual potential, enhance their mental activity, and increase the level of 
knowledge in mathematics [2], [3], [8], [10]. The identified requirements for the organization of didactic games include the following: 1) a game should be based on free creativity and independent activities of students; 2) a game should correspond to the age characteristics of students, its goal should be attainable for schoolchildren; 3) a mandatory element of the game is its emotionality, i.e. it should cause pleasure, cheerful mood, satisfaction from a successful result; 4) the presence of an element of competition between teams or individual participants; 5) a role of student activity during a game; 6) an educational and cognitive value of the game.

The psychological-pedagogical literature describes various classifications of didactic games. For example, by the nature of the cognitive activity, it is possible to distinguish games that require performing activities, with the help of these games schoolchildren perform actions along the pattern ("Make up a Pattern"); games that require the reproduction of actions are aimed at consolidating computing skills ("Computing Machines); there are also games that require transformative activity — with their help students change examples and tasks into others that are logically related to them ("Chain", "Mathematical Relay", "Drawing Circular Examples"); transformative activity also includes games that develop control skills and self-control ("Arithmetic Running"); games with elements of search and creativity ("Determine the Course of the Ship's Movement", "Help the Postman Pechkin"). Thus, a didactic game is a modern and recognized method of teaching, which has an educational, developmental, and educational function, prepares pupils of primary school age for the implementation of project activities in teaching mathematics.

In a profile school, project education creates conditions under which high school students independently and willingly acquire the missing knowledge from various sources; learn to use them for solving educational and practical tasks; acquire communication skills, working in different groups; develop research skills: identifying problems, collecting information, observing, conducting an experiment, analyzing, formulating hypotheses, and summarizing [4], [5], [6].

At the stage of theoretical substantiation, the features of implementing project activities at various stages of teaching mathematics were revealed. In accordance with the Federal State Educational Standard, a personally oriented approach in teaching was implemented. Personality-oriented teaching is based on the following didactic principles: self-actualization (the need to update their abilities); individuality (the creation of conditions for the formation of individual personality); variability (choice), it is advisable that everyone should be in conditions of constant choice; the principle of creativity and learning success; the principle of trust and support (humanistic personality-oriented educational technology); goal setting and motivation; the principle of openness (objective diagnosis, correction of pedagogical influences); the principle of orientation of training on the development of personality.

Based on the Federal State Education Standard, the primary school teacher chooses the subject of educational projects. Modern information and computer technologies allow a teacher to organize individual research extracurricular activities of schoolchildren, during which students have the opportunity to implement their research projects. A teacher, as a rule, offers a student a topic, a rough plan for its disclosure, and relevant literature. As results of their research, students have the opportunity to present in various scientific forums. For example, in 2016, the 4th All-Russian Youth Research and Practice Conference of the Orel State University named after I. S. Turgenev (Mathematics, Computer Science, Physics, Chemistry) with elements of a scientific school was attended by more than 200 students. There were reports that went far beyond the level of the school curriculum. For example, in the Mathematics section, the works "Nodes and Spit", (P., Grade 8), "Flexagons" (M., Grade 6), "The Eagle City Ecology in Text Problems" (A., Grade 6), "Mathematics in Football" (W., grade 6) were presented. In 2017, a group of Orel schoolchildren presented their projects in "Sirius" (Sochi).

If in a basic school, project activities are carried out, as a rule, individually under the guidance of a teacher, then in a specialized school, this is a group work. Studies have shown that creative groups should be distinguished as follows: collectors of materials; analysis (look at the collected material, forms requests for the necessary facts); designers. 1.5-2 months are allotted for a project as being implemented in extracurricular activities. There are the following stages of project activities: planning; development of evaluation criteria; performance; project presentation. It is advisable to describe in detail the system of actions of a teacher and students at different project stages, for example in the form of Table 1. 
TABLE 1. TEACHERS AND STUDENTS' SYSTEMS OF ACTION AT DIFFERENT STAGES OF AN EDUCATIONAL PROJECT.

\begin{tabular}{|c|c|c|}
\hline Stages & Teacher's activity & Students' activities \\
\hline \multicolumn{3}{|c|}{ 1. Development } \\
\hline \multirow{3}{*}{$\begin{array}{l}\text { 1.1. Choosing a project } \\
\text { theme }\end{array}$} & $\begin{array}{l}\text { A teacher selects possible topics and offers } \\
\text { them to students. }\end{array}$ & $\begin{array}{l}\text { Students discuss and make a general } \\
\text { decision on a topic }\end{array}$ \\
\hline & $\begin{array}{l}\text { A teacher invites students to jointly select a } \\
\text { project }\end{array}$ & $\begin{array}{l}\text { A group of students together with a } \\
\text { teacher selects topics and offers them for a } \\
\text { discussion }\end{array}$ \\
\hline & $\begin{array}{l}\text { A teacher participates in the discussion of } \\
\text { topics proposed by students }\end{array}$ & $\begin{array}{l}\text { Students independently select topics and } \\
\text { offer class for discussion }\end{array}$ \\
\hline \multirow{2}{*}{$\begin{array}{l}\text { 1.2. Selecting subtopics and } \\
\text { project themes }\end{array}$} & $\begin{array}{l}\text { A teacher preisolates sub-topics and offers } \\
\text { students to choose }\end{array}$ & $\begin{array}{l}\text { Each student chooses a subtopic or } \\
\text { offers a new one }\end{array}$ \\
\hline & $\begin{array}{l}\text { A teacher participates in a discussion with } \\
\text { project subthemes }\end{array}$ & $\begin{array}{l}\text { Students actively discuss and suggest } \\
\text { subtopic options. Each student chooses } \\
\text { one of them (i.e. choose a role) }\end{array}$ \\
\hline 1.3. Forming creative groups & $\begin{array}{l}\text { A teacher conducts organizational work to } \\
\text { unite schoolchildren who have chosen } \\
\text { specific subthemes and types of activities }\end{array}$ & $\begin{array}{l}\text { Students have already defined their roles } \\
\text { and are grouped according to them into } \\
\text { small teams. }\end{array}$ \\
\hline $\begin{array}{l}\text { 1.4. Preparing materials for } \\
\text { research work: formulation of } \\
\text { questions to be answered, task } \\
\text { for teams, selection of literature }\end{array}$ & $\begin{array}{l}\text { If a project is voluminous, the teacher } \\
\text { prepares tasks, questions for search } \\
\text { activities and literature in advance }\end{array}$ & $\begin{array}{l}\text { Individual students of senior and middle } \\
\text { classes are involved in the development of } \\
\text { tasks. Questions for finding an answer can } \\
\text { be generated in teams followed by class } \\
\text { discussion }\end{array}$ \\
\hline $\begin{array}{l}\text { 1.5. Defining forms of } \\
\text { expression of the results of } \\
\text { project activities }\end{array}$ & A teacher participates in the discussion & $\begin{array}{l}\text { Students in groups and then in the } \\
\text { classroom discuss possible forms for } \\
\text { presenting their research result: a video } \\
\text { film, an album, natural objects, a literary } \\
\text { drawing room, etc. }\end{array}$ \\
\hline 2. Developing a project & $\begin{array}{l}\text { A teacher consults, coordinates students' } \\
\text { work, and stimulates their activity }\end{array}$ & Students carry out research activities \\
\hline 3. Registering results & $\begin{array}{l}\text { A teacher consults, coordinates students' } \\
\text { work, and stimulates their activities }\end{array}$ & $\begin{array}{l}\text { Students, first in groups and then in } \\
\text { collaboration with other groups, process } \\
\text { results in accordance with accepted rules }\end{array}$ \\
\hline 4. Presentation & $\begin{array}{l}\text { A teacher organizes the examination (for } \\
\text { example, invites senior schoolchildren } \\
\text { from a parallel class, or parents as experts) }\end{array}$ & Report on research results \\
\hline 5. Reflection & $\begin{array}{l}\text { Evaluates the work done on the quality of } \\
\text { assessments and activity of students }\end{array}$ & $\begin{array}{l}\text { Summing up their work, provide } \\
\text { feedback, collectively assess their } \\
\text { experiences. }\end{array}$ \\
\hline
\end{tabular}

Of particular importance in the implementation of project activities is the phase of reflection, which involves students assessing project results. For this purpose, the study used achievement maps; questionnaires, surveys on the definition of personal gains; self-evaluation sheets, which contained the following sections: "Evaluation Criteria," "My Evaluation," "Group Evaluation," and "Evaluation of the Manager".

Each project participant in the self-assessment sheet answers the following questions: "I compiled questions for the project", "I conducted research", "I selected the necessary tasks", "I worked on PC", "I actively worked with project participants", "I studied how to speak competently, concisely, clearly, specifically", "I helped my classmates in solving problems", "I realized what strategies I need to learn better".

In order to assess project activities, it is important to develop parameters for an external evaluation of a project, which take into account: a) significance and relevance of the problems raised and the adequacy of their studied subjects; b) correctness of the research methods being used and the method of processing the 
results obtained; c) project participants' activities in accordance with their individual capabilities; d) the collective nature of decisions; e) the nature of communication and mutual assistance, project participants' complementarity; e) the necessary and sufficient depth of going into the problem, using knowledge from other areas; g) evidence of the decisions made, the ability to argue their conclusions; $h$ ) aesthetics of the design of the results of the completed project; i) the ability to answer questions of opponents, conciseness, and reasoning of the answers of each member of the group. It is desirable to attract a number opponents from among those specialists who are professionals in the sphere for which a particular project was developed.

Evaluation criteria of the project can be, for example, as such:

1. How well a presentation is done (uniform design styles, various kinds of objects on slides, animated objects, correct text presentation, objects made in other programs) - 20 points.

2. How correct a presentation is (goals, hypotheses, objectives, research methods, experiments, the course of the research, reliability of results, robust conclusions, etc.) - 20 points.

3. Results of conversations with representatives of the professional sphere -10 points.

Great job: 41-50 points; good job: 32-40 points; satisfactory performance: $24-31$ points; a project needs refinement; $15-23$ points; weak performance: 0-14 points.

The pedagogical significance of the project method is as follows: it is the cultivation of emotionalaxiological attitudes towards events, phenomena of social life, history and cultural traditions. Projects allow to experience diverse activities, during which such necessary skills and abilities are formed. Educational projects are an opportunity to create a situation of success, both personal and collective, and such success gives confidence in one's own strength, stimulates activity, and contributes to self-development and improvement. The study showed that project activities in the process of teaching mathematics are truly relevant and effective. The project method gives a student the opportunity to experiment, synthesize knowledge, develop creative abilities and communication skills, which would allow a student to successfully adapt in society. However, it cannot be assumed that project activities alone will solve all the problems of modern education. Project activities should only be used in conjunction with traditional and other innovative learning technologies. It should be noted that the ability to use project activities in their work and to organize them is an indicator of the teacher's high qualification. It is not without reason that this technology is referred to as the technology of the 21 st century, implying, above all, the ability to adapt to the rapidly changing conditions of the information society.

\section{Conclusion}

The study showed the benefits of using project activities in the educational process: it systematizes teachers' work of the teacher, develops students' autonomy in self-expression, relies on personal choice and interest, providing, therefore, much deeper motivation. The complexity of the tasks being solved during an educational project allows each teenager to be included in a common endeavor that is personally feasible, taking into account age and individual characteristics. The essence of project training is that each participant in the process of working on an educational project comprehends real processes and objects. To comprehend, live, join the disclosure, design, we need special forms of training. The leading among them is a simulation game. Such a game is the most free, natural form of immersion of a person into real (or imaginary) reality with the purpose of studying it, manifesting one's own "I", creativity, activity, independence, self-realization. It is in a game that everyone chooses a role voluntarily, going through social adaptation in the process of project activity.

\section{References}

[1] Alekseev, N. A. (2016). Personality-oriented education in school. Rostov-on-Don, Russia: Fenix.

[2] Dewey, J., \& Dewey, E. (1922). Schools of the future. Berlin, Germany: State Publishing House.

[3] Dewey, J. (2000). Democracy and education. Moscow, Russia: Pedagogika-Press. 
[4] Collings, E. (1926). The E=experience of American schools in the method of projects. Moscow, Russia: New Moscow.

[5] Polat, E. S. (1995). How the project is born. Moscow, Russia: Enlightenment.

[6] Selevko, G. K. (1998). Modern educational technology. Moscow, Russia: National Education.

[7] Serikov, V. V. (1994). Pedagogy, 5, 78-84.

[8] Epstein, M. M. (2011). At historical crossroads: method of projects. St. Petersburg, Russia: Participation Educational Center.

[9] Yakimanskaya, I. S. (1996). Personality-oriented education in the modern school. Moscow, Russia: Education.

[10] Shikhnabieva, T., \& Beshenkov, S. (2016). Intelligent system of training and control of knowledge, based on adaptive semantic models. In Smart Education and e-Learning (pp. 595-603). Berlin, Germany: Springer International Publishing.

[11] Uskov, V. L., \& Uskov, A. V. (2007). Advanced Technology for Learning, 4(3), 56-69. 